\title{
熱中性子によって生ずる放射能の簡易計算法
}

\author{
岡田実 \\ 日本原子力研究所東海研究所
}

放射性核種の製造に遅い中性子を使う場合，中性子 エネルギーが広い範囲に分布していることが多い。し かし，生成放射能を計算するに当たって計算を簡単に する心熱中性子に着目し, そ机以外の中性子を無視 するのがふつらである。

そこで，熱中性子を使う場合の簡易計算法をここに 説明ける。

\section{計 算 法}

（1）図 2 の曲線を図 1 に重ねる。そのさい，（i ）曲 線の水平部分を図 1 の横軸に平行に保ち, (ii )曲線上 のP点が「照射時間に等しい目盛」の上に来るように する。

照射時間が 1 時間の場合は図 3 のとおりになる。

(2) この曲線を上下に移動させることによって問題 の点が曲線に乗るようにする。

ルテシウムとヨウ素と金の 3 例を図 4 に示す。

（3）曲線の水平部分の高さを縦軸の目盛で読む。
ルテシウムの例では「ルテシウム $1 \mathrm{mg}$ あたり 7 × $10^{\circ} \mathrm{mCi}$ の ${ }^{176 m} \mathrm{Lu}$ が生ずる」という答が読み取れ。 る。

なお，利用する熱中性子束が異なる場合には，その 熱中性子束と $1 \times 10^{13}$ との比を図 1 の縦軸目盛の值に 掛けて得られる新しい目盛を使えばょい。

\section{この計算法の原理 ${ }^{1), 2}$}

天然元素から成る陚料に熱中性子を $t$ 秒間照射する ことによって試料内の一核種から生ずる放射能 $A_{t}$ $\left(\mathrm{sec}^{-1}\right)$ はつぎの式で表わされる。

$$
A_{t}=f \sigma_{\mathrm{ac}} N\left(1-e^{-\lambda t}\right)
$$

ここに $f$ は熱中性子束 $n\left(\mathrm{~cm}^{-2} \cdot \mathrm{sec}^{-1}\right), \sigma_{\mathrm{ac}}$ は問題と する天然核種の熱中性子放射化断面積 $\left(\mathrm{cm}^{2}\right), N$ は問 題とする天然核種の原子の数， $\lambda$ は生成した放射性核 種の壊変定数 $\left(\mathrm{sec}^{-1}\right)$ である。 $N$ と $\lambda$ は周知のとおり それぞれつぎの式で表わされる。

$$
N=N_{\mathbf{A}}(W / M) K
$$

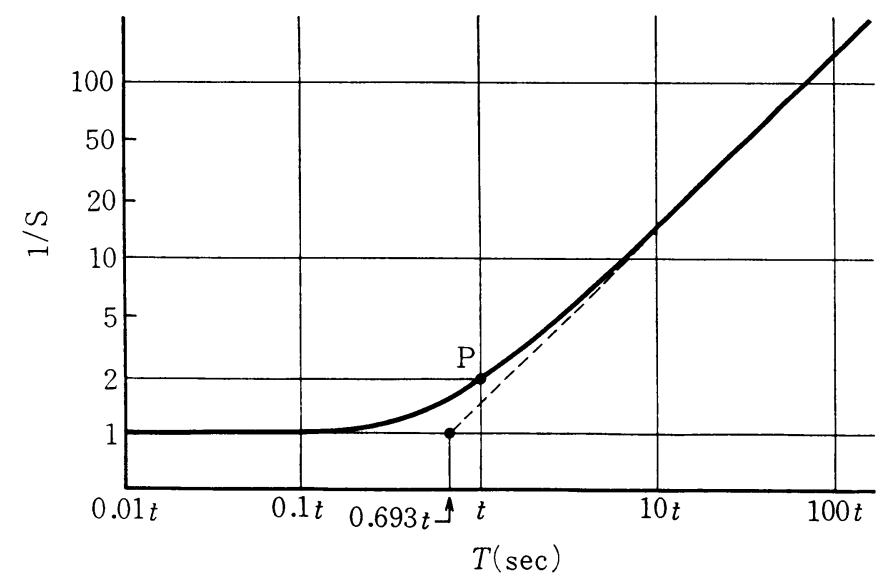

図 2 等放射化線の形

$$
\lambda=\ln 2 / T
$$

ここに $N_{\mathrm{A}}$ は Avogadro 数, $W$ は問題 とする天然 元素の量 $(\mathrm{g}), M$ はその元素の原子量, $K$ はその元素 の中に打ける問題の天然核種の存在度, 寸なわち原子 $\dagger$ Rapid Estimation of Thermal Neutron Activation, Minoru OKadA: Japan Atomic Energy Research Institute, Tokai Research Establishment, Tokai, Ibaraki. 


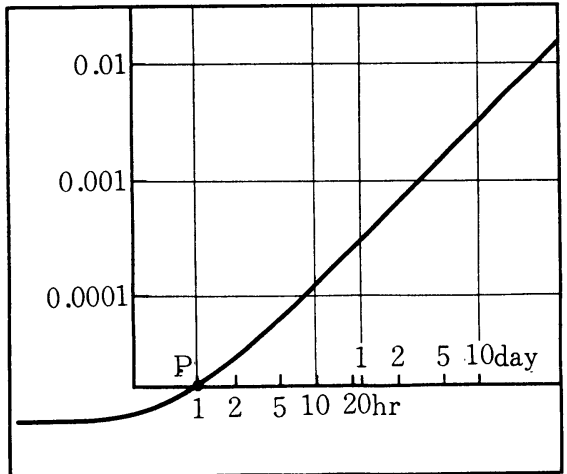

図 3 図式計算において照射時間を入れる方法の 一例。照射時間が 1 時間の場合。

数比，Tは生成した放射性核種の半減期( $\mathrm{sec}$ )である。 いま $1-e^{-\lambda t} \equiv S$ と置けば，（1)〜（3)式からつぎ の式が得られる。

$$
\left\{\begin{array}{l}
\frac{\sigma_{\mathrm{ac}} K}{M}=\frac{A_{t}}{N_{\mathrm{A}} f W} \cdot \frac{1}{S} \\
S=1-e^{-(\ln 2) t / T}
\end{array}\right.
$$

両対数方眼紙の縦軸に $\sigma_{\mathrm{ac}} K / M$ を取り横軸に生成 核種の半減期を取って天然核種を図中に配置すると図 5 が得られる。図の左上の部分にある核種は短時間に 強く放射化される。また，短時間の照射によって，図 の左下の部分にある核種を含む元素は, 図の右上にあ る核種を含む元素と同じ程度に放射化される。たとえ ば 1 時間以下の照射による水銀とセシウムの放射化は 同程度である。両核種を図上で結ぶ線は等放射化線と も言うべきものである。つぎに, この線の形を求め る。

$f$ 一定といら条件のもとで時間 $t_{1}$ だけ照射するこ とによってたがいに等しい比放射能に到達するような 諸元素を考え, これらの元素における「生成核種の半 減期 $T$ と $\sigma_{\mathrm{ac}} K / M$ との関係」をまず求める。いま, 比放射能 $A_{l} / W$ が一定であるから(4)式中の $A_{t} /\left(N_{\mathrm{A}}\right.$

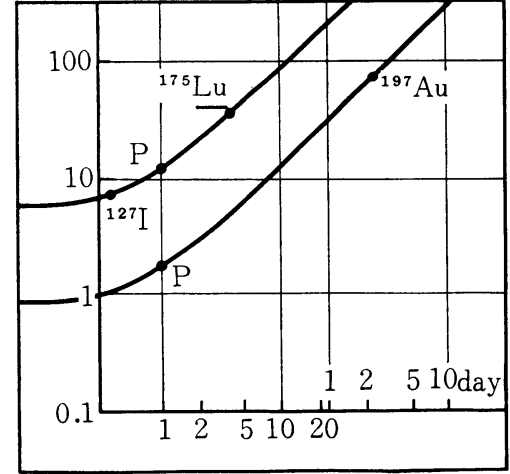

図 41 時間照射の場合の計算において元素の種 類を入れる方法の例。上はヨウ素とルテシ ウムの例。下は金の例。

$f W)$ は一定である。したがって「Tと $\sigma_{\mathrm{ac}} K / M$ の関 係」を見る代わりに「Tと $1 / S$ の関係」を見ればよ い。そこで, 両対数方眼紙の横軸に $T$ を取り縦軸に $1 / S$ を取り（5)式によって図 2 の曲線を描くと，これ が等放射化線の形である。罒からわかるようにこの 曲線には 2 本の漸近線がある。

図 2 の曲線上で $T=t_{1}$ の点を $\mathrm{P}$ とす。

前記の計算法の(1)〜（2）にならって図 2 を図 5 に 重ねたとき，曲線に乗るいくつかの核種が等放射化元 素を示す。等放射化元素の例は図 4 にも女る。

$f$ と $S$ に適当な值を与えることによって図 5 の縦軸 を $A_{t} / W$ 值で目盛ることができる。図 1 はその一例 であって, $f=1 \times 10^{13} n \mathrm{~cm}^{-2} \cdot \mathrm{sec}^{-1}$ と $S=1$ を与えた ๖のである。

図 5 には省略したが，ウランの $(n, f)$ 反応で生ず る核種に対応する多数の点は $1.4 \times 10^{-27} \mathrm{~cm}^{2}$ よりる下 にある ${ }^{3)}$ 。

\section{文献】}

1）岡田実 : 東工試, 58, $1 \sim 6$ （1963）

2）岡田実：同位体と放射線，3，189～205（1960）

3）岡田実 : 東工武, 58, 58〜63 (1963) 


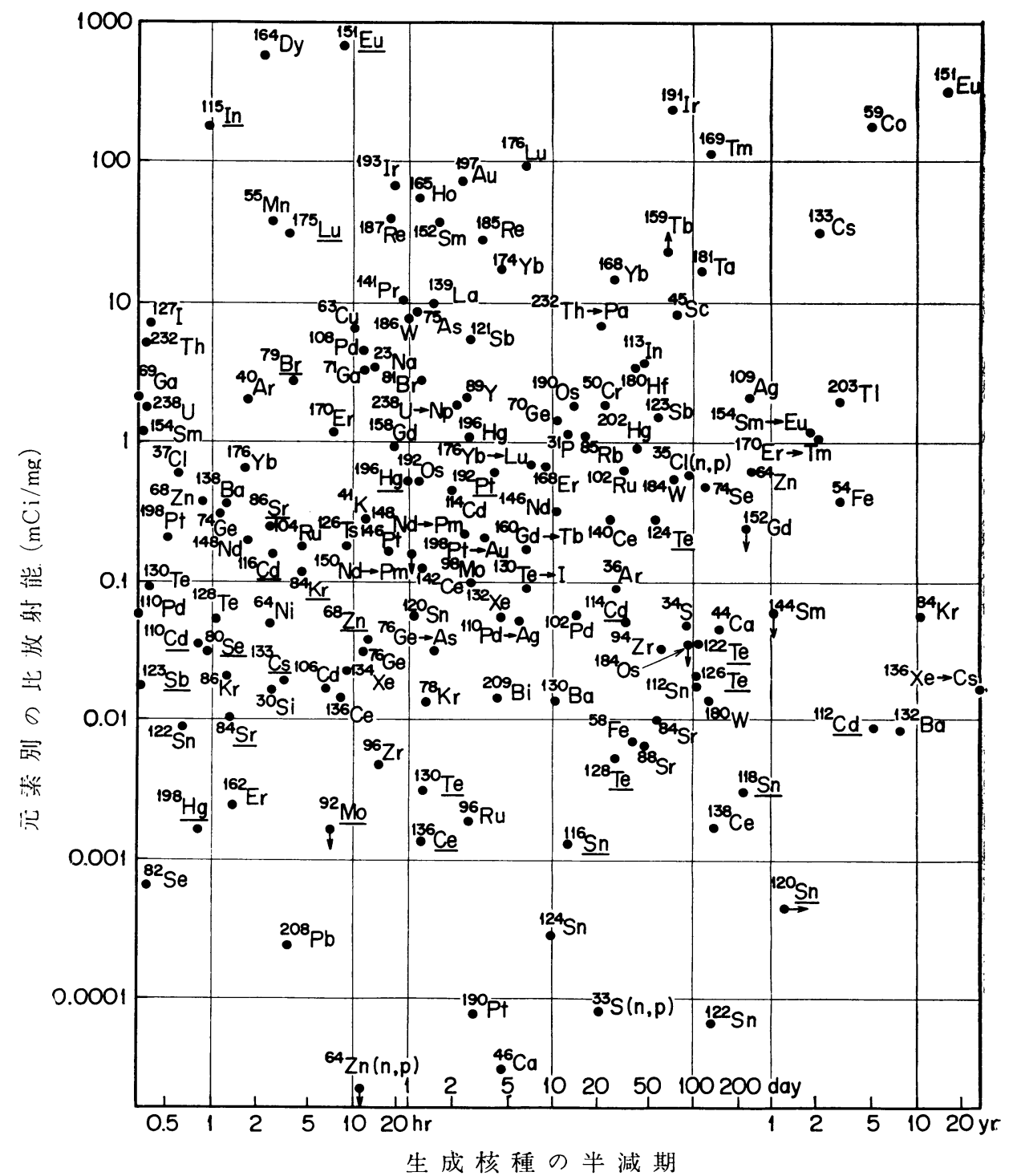

図 $11 \times 10^{13} n \mathrm{~cm}^{-2} \cdot \mathrm{sec}^{-1}$ の熱中性子によって半減期 20 分〜30 年の放射性核種を天 然の元素から作る場合に使える放射能計算図表。図中の核種名はターゲットの 核種。反応を付記したもの以外は $(n, \gamma)$ 反応。下線を付けた核種は反応によっ て準安定核種になる。 


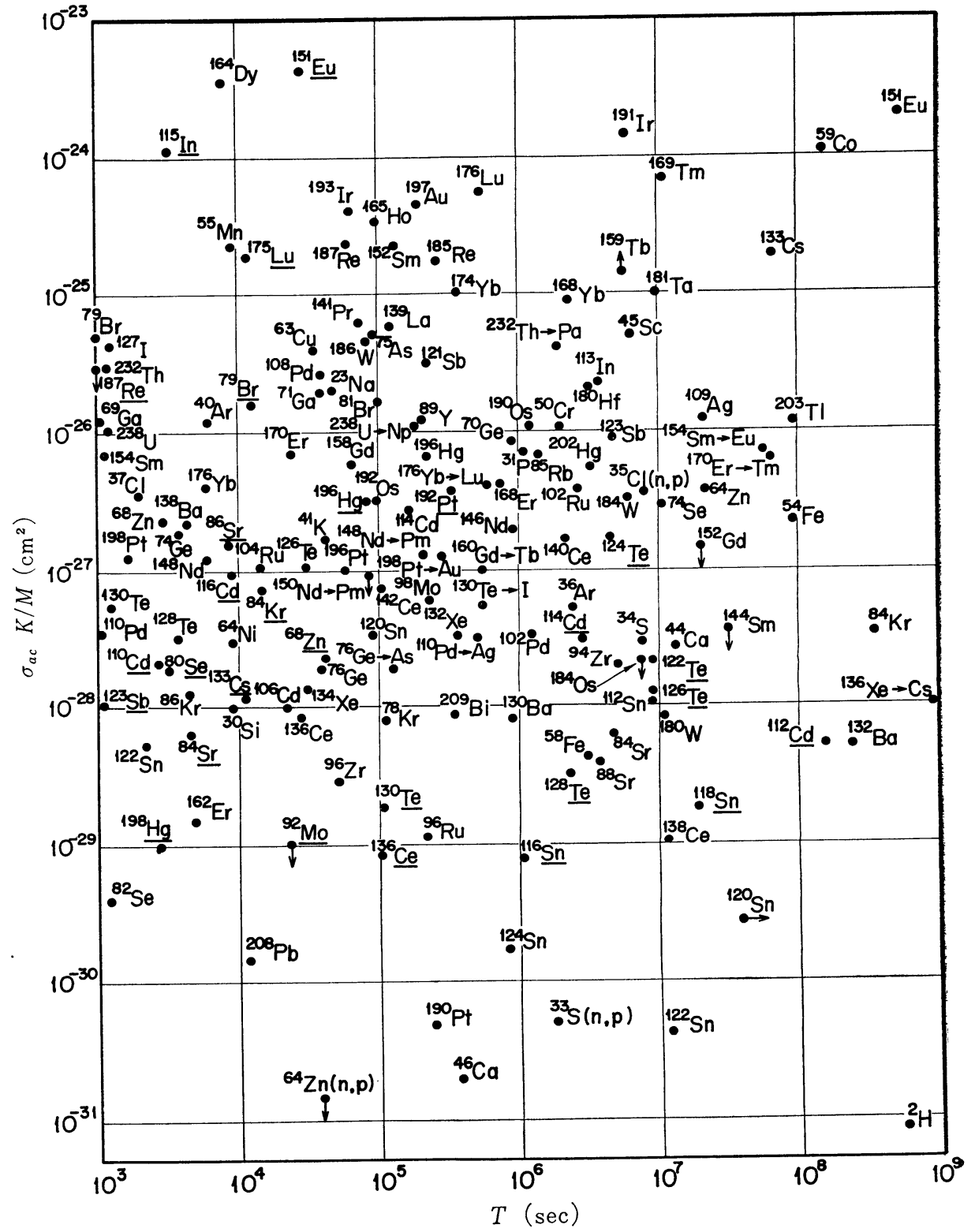

図 5 天然に存在する核種を「天然に存在する元素 $1 \mathrm{amu}$ あたりの熱中性子放射化断 面積」と「生成核種の半減期」とによって配列した図。反応を付記したもの以外 は $(n, \gamma)$ 反応。下線を付けた核種は反応によって準安定核種になる。 